\title{
On the Origins of the Fleming-Mundell Model
}

\author{
JAMES M. BOUGHTON* \\ Forty years ago, Marcus Fleming and Robert Mundell developed independent \\ models of macroeconomic policy in open economies. Why do we link the two, and \\ why do we call the result the Mundell-Fleming, rather than Fleming-Mundell \\ model? [JEL B31, E12, F41]
}

King: Thanks, Rosencrantz and gentle Guildenstern.
Queen: Thanks, Guildenstern and gentle Rosencrantz.

Hamlet, Act II, Scene 2

n the early 1960s, J. Marcus Fleming and Robert Mundell independently extended the open-economy Keynesian model of macroeconomic policy to incorporate systematically the role of capital flows. Both contributions quickly became influential, and for more than a decade a diversified literature developed in which Fleming and Mundell were seen as important contributors to the general theme. ${ }^{1}$ In 1976, Rudiger Dornbusch published a series of articles on exchange rate policy that

\footnotetext{
*James M. Boughton is an Assistant Director in the IMF's Policy Development and Review Department and was Historian of the IMF from 1992 to 2001. The author is grateful to, but does not wish to implicate, June Flanders, Robert Flood, Peter Kenen, Maurice Obstfeld, Jacques Polak, and Kenneth Rogoff for suggestions on earlier drafts.

${ }^{1}$ In 1965, Anne Krueger included Fleming and Mundell, along with Rudolf Rhomberg and Egon Sohmen, as important contributors to the development of the open-economy macromodel. Sven Arndt (1973) referred to the "Tinbergen-Mundell model" and included Fleming in a list of other contributors. Alfred Steinherr (1975) gave cobilling to James Meade, Mundell, and Fleming. Edward Tower (1972), Jay Levin (1972), and Richard Cooper (1976) gave primary credit to Fleming. Alexander Swoboda (1972), Rishi Kumar (1973), Vicente Galbis (1975), and S.C. Tsiang (1975) attributed the model primarily to Mundell. Victor Argy and Michael Porter (1972) regarded Fleming and Mundell as joint contributors. Robert Cherneff (1976) suggested that Mundell introduced the device of the foreign balance curve while Fleming first derived the effects of fiscal policy on the external balance. Russell Boyer (1978) suggested that Mundell's model was built on Lloyd Metzler's (1951) closed-economy model, and he gave joint credit to Fleming and Mundell for the policy analysis. None of this literature gave a name to the model or the general approach. Kenen (1965, p. 145n) used the phrase "Fleming-Mundell model" in a different context, referring to the analysis of forward exchange markets developed in the one paper that the two wrote jointly (Fleming and Mundell, 1964).
} 
codified these contributions into what he called the Mundell-Fleming model. ${ }^{2}$ Ever since, that terminology and that version of the model have dominated the literature on open-economy macroeconomics. The separate contributions of the two men have thereby become blurred, and the reverse sequencing of their names has seldom been questioned. The primary exception has been Peter Kenen $(1985,1994)$, who has consistently used the more natural alphabetical ordering, Fleming-Mundell. ${ }^{3}$

At the time that Fleming and Mundell were writing, the prevailing openeconomy analysis in the Keynesian tradition was that of James Meade. Meade's description of the effects of monetary and fiscal policies was concerned primarily with sorting out the differential effects on internal and external balance, and he regarded differences between monetary and fiscal policies as of secondary importance and relevant mainly to the capital account:

\begin{abstract}
We may conclude, therefore, that while fiscal and monetary methods of inflating or deflating domestic expenditure will have broadly similar results on the national incomes and balances of trade of the countries concerned, the monetary method of reducing interest rates may cause a significantly larger increase in the transfer of capital funds abroad and thus involve a significantly larger unfavourable movement in its total balance of payments. ${ }^{4}$
\end{abstract}

Fleming (1962) refocused Meade's analysis to examine the consequences of a country's choice of exchange regime on the effectiveness of fiscal and monetary policies for regulating domestic output. His contribution was not in extending Meade's framework, but in simplifying it and directing it to a particularly interesting policy problem. Monetary policy, he argued, was more effective under floating exchange rates, both in absolute terms and relative to a fiscal policy action of a given size. He also showed that the effect of floating on the effectiveness of fiscal policymeasured as an autonomous change in domestic spending with a fixed stock of money-was ambiguous. These conclusions were based on a comparative static analysis of an open-economy Keynesian expenditure (IS-LM) model, augmented with a relation between capital flows and the domestic rate of interest. The mathematical relationships were illustrated in an appendix with a model comprising four income-expenditure identities and five behavioral equations. ${ }^{5}$

\footnotetext{
${ }^{2}$ As far as I have been able to determine, Dornbusch (1976a and b) and Dornbusch and Krugman (1976) contain the first published references to the term "Mundell-Fleming model." Dornbusch's 1980 textbook made it a household name in the profession.

${ }^{3}$ Other post-1976 references to the Fleming-Mundell model include Turnovsky and Kingston (1977), Rodriguez (1979), Tobin and Braga de Macedo (1980), and Baumgarten and Linsenbühler (1985). The 1985 Jones-Kenen Handbook of International Economics includes this index entry: "Mundell-Fleming model; see Fleming-Mundell model" (p. 1237). Most references in the text, however, refer to the MundellFleming model except those by Kenen (Fleming-Mundell), Richard Cooper (Meade-Fleming-Mundell), and John Helliwell and Tim Padmore (also Meade-Fleming-Mundell). Chen, Lai, and Chang (1987) refer to the Fleming model and mention Mundell as a contributor to the tradition. Obstfeld and Rogoff (1996, p. 609) christened it the Mundell-Fleming-Dornbusch model, in recognition of Dornbusch's incorporation of rational expectations into the model.

${ }^{4}$ Meade (1951a), p. 104.

${ }^{5}$ For an exposition, see the appendix to this paper. Meade's analysis was based on a 23-equation general equilibrium model that was more rigorously underpinned by microeconomic theory but also much more opaque than the IS-LM model. See Meade (1951b).
} 
Mundell developed his analysis in a series of four articles (1960, 1961a and b, and 1963). The first one introduced what he called the "principle of effective market classification": the idea that a policy instrument should be assigned to the target over which it has the strongest (relative) influence. Starting from a twoequation variant of Laursen and Metzler's (1950) model, rearranged to derive equilibrium in markets for goods and services and for foreign exchange (see this article's appendix), he developed the dynamic adjustment of internal and external balance in response to monetary shocks. Whether monetary (that is, interest rate) policy should be directed toward internal or external balance was shown to depend on whether the exchange rate is floating or fixed. Subsequent articles expanded on this theme and showed that a range of alternative policies could be used to restore external balance if monetary policy were assigned to internal balance (1961a); that in the general case, monetary and fiscal policies are both more effective for restoring internal balance under flexible than fixed exchange rates, but the advantage for monetary policies is greater (1961b); and that in an extreme case with perfect capital mobility, fiscal policy will be ineffective for restoring internal balance (1963). ${ }^{6}$

What has become known vernacularly as the Mundell-Fleming model is essentially Fleming's equations combined with Mundell's policy analysis. ${ }^{7}$ Much of the analysis, as has often been observed, can be extracted from Meade by a careful reader, ${ }^{8}$ but it was not well understood until Mundell presented it clearly and elegantly. In this observation, there is an analogy with the Keynesian expenditure multiplier, which was developed first by Richard Kahn (1931) but became an essential tool for policy analysis only when Keynes embedded it into his General Theory (1936). Just as the phrase "Keynes-Kahn multiplier" still surfaces occasionally, various linkages of Meade, Fleming, and Mundell may be found in the literature but not in the broader professional consciousness.

The open-economy macromodel has, of course, developed well beyond the simple short-run systems analyzed by Fleming and Mundell forty years ago. ${ }^{9}$ The core is nonetheless intact, and it is worth recalling its origins. To do so requires sorting out the interactions between two authors who were not only contemporaries but also-for a brief period-close colleagues.

Marcus Fleming joined the staff of the Research Department at the IMF in 1954 and while he was working on his model was an Advisor in charge of the Special Studies Division. (He eventually became Deputy Director and continued working at the Fund until his death in 1976.) Robert Mundell officially joined the IMF staff in

${ }^{6}$ Footnote 5 in Mundell (1963) provides a detailed reconciliation of the apparent contradictions with his 1961 b conclusions.

${ }^{7}$ As Mundell and others have noted, Fleming's model is not internally consistent for long-run analysis, because the money supply cannot be held fixed while fiscal policy is varied in a fixed exchange rate system with high capital mobility. The appropriate monetary control variable is either the nominal interest rate, as in Mundell's analysis, or domestic credit, as in the Keynesian version of the monetary approach to the balance of payments developed by Jacques Polak $(1957,1998)$.

${ }^{8}$ Lloyd Metzler $(1951,1960)$ was another important and seminal influence on the analysis of the monetary role of capital flows. For a good exposition of the contributions of Metzler and Meade to this line of analysis, see Flanders (1989), Chapter 16.

${ }^{9}$ For a comprehensive review of the first 25 years of developments, see Frenkel and Razin (1987). Subsequent developments, including notably the exposition of the model's microfoundations by Maurice Obstfeld and Kenneth Rogoff, are surveyed in Rose (2000), pp. 215-19. 
August 1961 as an economist in Fleming's division, though he did not physically arrive from Italy (where he had been teaching) until mid-September. ${ }^{10}$ He had been recommended to Fleming by Paul Samuelson in June 1960 as an outstanding young theorist in international trade. Arnold Harberger, Charles Kindleberger, and Lorie Tarshis all added their recommendations, also based on Mundell's work on trade theory. When Fleming and Jacques Polak (Director of Research) reviewed Mundell's credentials, they had available some of his published articles, all on trade theory. Mundell also knew Fleming by reputation, but the two did not meet until Mundell arrived at the Fund. Nothing in the record indicates that Fleming had read Mundell's work on the open-economy macromodel before this time. ${ }^{11}$

Fleming published a draft of his article internally in the IMF in November 1961, as a "departmental memorandum," which at the time was the standard vehicle for circulating working papers on staff research. That draft was nearly identical to the version published the following year in the IMF's quarterly journal, Staff Papers, except that it did not include the mathematical appendix. Since, as Mundell has recalled (Mundell, 2001, p. 221), Fleming was away when he arrived in September, and since some time would have been necessary for preparation and distribution of the manuscript in the age of typewriters and mimeograph machines, Fleming's article must have been substantially completed before he and Mundell met.

Fleming is not known to have commented on the relative timing or the independence of his and Mundell's contributions. Mundell has reflected on the relationship, though he has provided slightly varying explanations. In 1978, in a commemorative essay on Fleming (Fleming, 1978, p. xix), he came close to claiming primacy:

Marcus that year [1961] was active in the theater . . . but nevertheless
managed to write a paper on the monetary-fiscal mix that built upon the
subject I had worked on, and he produced a paper that is still worth read-
ing today by students.

More recently, however, he has described the history in more nuanced terms. After noting that "I wish Marcus Fleming could have been here to fill in the blanks from his point of view and redress the balance" (Mundell, 2001, p. 215), he acknowledged that Fleming "had probably been working on his model before I arrived at the Fund," and then added "and of course my papers owed nothing to his" (p. 223). He also claimed that Fleming had read at least four of his papers on the subject, and he concluded that Fleming's "work, if not dependent on mine, at least followed mine, whereas mine was completely independent of his" (p. 225). ${ }^{12}$

\footnotetext{
${ }^{10}$ For a brief biography of Fleming, see the introduction to Fleming (1978). For one of Mundell, see the website of the Nobel Foundation (http://www.nobel.se/economics/laureates/1999/mundell-bio.html).

${ }^{11}$ As indicated by a note filed in the IMF archives, Polak's secretary checked out four journals from the library in August 1960, three of which contained articles by Mundell on trade theory but not on macroeconomics.

${ }^{12}$ In that speech, Mundell continued, "I am not suggesting Fleming's work wasn't in an important sense independent of mine. It was certainly to a large extent subjectively (to use Schumpeter's phrase) original." In a later version (Mundell, 2002), he replaced that last sentence with "Mine preceded his in publication but not necessarily in conception."
} 
Further complicating this version of events is the fact that Mundell misremembered a crucial part of the sequence. "When he [Fleming] was putting the finishing touches on his own paper in the spring of 1962," Mundell recalled nearly 40 years later, "he asked me which of my articles I thought he should refer to" (Mundell, 2001, p. 223). Mundell concluded that this discussion led Fleming to cite his article in the Canadian Journal of Economics and Political Science (Mundell, 1961b). But that citation is already in the version of Fleming's paper circulated in November 1961. The footnote (p. 2n) reads:

\footnotetext{
The only clear cut alternative [to holding the stock of money fixed] would appear to be that of defining constancy of monetary policy as the maintenance of a constant rate of interest. In a forthcoming article in the Canadian Journal of Economics and Political Science (November 1961), Mr. R. A. Mundell compares the effects of monetary policy (thus defined as interest policy), fiscal policy and commercial policy in a flexible exchange rate system and a fixed exchange rate system respectively.
}

This note was virtually unchanged, except for some stylistic editing and an updating of the citation, in the version published a year later in Staff Papers. Since Mundell joined Fleming at the Fund only a few weeks before the internal circulation of Fleming's paper, the reported conversation must have taken place in October 1961 or even at the beginning of November, when Fleming's article was already substantially finished and before Mundell's was published. It is, of course, possible that Fleming had read Mundell's earlier work on this subject in the course of his research, but for him to ask Mundell at this late stage "which article he should refer to" implies that the linkage was an afterthought.

All available evidence thus suggests that the models of Fleming and Mundell were derived independently and approximately contemporaneously. Both models influenced the thinking of the generation of economists who extended their work in the late 1960s and throughout the 1970s. The parallel linkage of the names of Marcus Fleming and Robert Mundell is therefore a proper tribute to their closely related but separate contributions to the development of modern international macroeconomics. Although the Dornbuschian reversal into the "Mundell-Fleming model" is now firmly entrenched, the more natural alphabetical ordering-the Fleming-Mundell model—is at least equally justified.

\section{APPENDIX}

The comparative static properties of the two original models can be readily compared.

\section{The Fleming Model}

Fleming (1962, p. 377) presented his model as an extension of the Hicks-Hansen IS-LM model. With some modification of the notation, the Fleming model may be written as

$$
\begin{aligned}
& z \equiv x+g \\
& y \equiv z+b
\end{aligned}
$$




$$
\begin{aligned}
& v \equiv y / m \\
& n \equiv y-t \\
& t=t(y) \\
& x=x(n, r) \\
& r=r(v) \\
& b=b(z, e) \\
& k=k(r)
\end{aligned}
$$

where, in order of appearance,

$$
\begin{aligned}
& z=\text { total expenditure } \\
& x=\text { private expenditure } \\
& g=\text { government expenditure } \\
& \mathrm{y}=\text { national income } \\
& b=\text { trade balance } \\
& v=\text { velocity of money } \\
& m=\text { stock of money } \\
& n=\text { private income } \\
& t=\text { tax payments } \\
& r=\text { interest rate } \\
& e=\text { exchange rate (domestic currency price of foreign exchange) }
\end{aligned}
$$

and

$$
k=\text { net capital inflow. }
$$

The first seven equations, with $b=0$, constitute the basic IS-LM model. As written, this version is incomplete and requires a policy rule; see Fleming (1962), p. 378. Let $b+k=\Delta R$, where, with floating exchange rates, $\Delta R=0$. At the other extreme, $\Delta e=0$. In intermediate cases (managed floating), either $R$ or $e$ is a policy instrument.

The Fleming model may be reduced to three excess-demand equations that can be solved for $y, r$, and $e$ (or $R$, if $e$ is fixed) as functions of $m, g$, and $R$ (or $e$, if $R$ is fixed).

$$
\begin{aligned}
& y(y, g, r, e)=0 \\
& v(y, r, m)=0 \\
& f(y, r, e, R)=0
\end{aligned}
$$

In the fixed exchange rate case, the first two of these equations constitute a closed block for internal balance. Otherwise, the system is simultaneous.

\section{The Mundell Model}

Mundell presented his model in a general semi-reduced form that may be compared directly with the solution of the Fleming model derived above. The equation system varied from one article to the next. The following representation is a composite of versions discussed in Mundell (1961a), p. 155n, and Mundell (1960), p. 256, with the notation modified for consistency:

$$
\begin{aligned}
& y(y, r, p \cdot e)=0 \\
& m(y, r, m)=0 \\
& f(y, r, p \cdot e)=0
\end{aligned}
$$


with the additional notation that $p=$ the ratio of domestic to foreign price levels (held fixed in the Fleming model). This change makes the whole system simultaneous even in the fixed exchange rate case, because the real exchange rate $(p \cdot e)$ is endogenous. The other main difference is that Mundell treats the interest rate, rather than the stock of money, as the monetary control variable. This equation system therefore can be solved for $y, m$, and $p \cdot e$ as a function of $r$. Fiscal policy $(g)$ can be added in exactly the same manner as in the Fleming model. In the floating rate case with perfect capital mobility, equations (M.1) and (M.3) can be solved independently, and monetary policy drops out.

\section{REFERENCES}

Argy, Victor, and Michael G. Porter, 1972, “The Forward Exchange Market and the Effects of Domestic and External Disturbances under Alternative Exchange Rate Systems," Staff Papers, International Monetary Fund, Vol. 19 (November), pp. 503-32.

Arndt, Sven, 1973, "Policy Choices in an Open Economy: Some Dynamic Considerations," Journal of Political Economy, Vol. 81 (July/August), pp. 916-35.

Baumgarten, Klaus, and Georg Linsenbühler, 1985, “An Integrated Portfolio Model of a Small Open Economy, or Fleming-Mundell Revisited," Jahrbücher für Nationalökonomie und Statistik, Vol. 200 (May), pp. 262-79.

Boyer, Russell S., 1978, "Financial Policies in an Open Economy," Economica, Vol. 45 (February), pp. 39-57.

Chen, Chau-nan, Ching-chong Lai, and Wen-ya Chang, 1987, "The Tight Money Effect, Wage Indexation, and Macroeconomic Policy: The Fleming Model Revisited," Journal of Economic Studies, Vol. 14, No. 5, pp. 54-62.

Cherneff, Robert V., 1976, "Policy Conflict and Coordination Under Fixed Exchanges: The Case of an Upward Sloping IS Curve," Journal of Finance, Vol. 31 (September), pp. 1219-24.

Cooper, Richard N., 1976, "Monetary Theory and Policy in an Open Economy," Scandinavian Journal of Economics, Vol. 78, No. 2, pp. 146-63.

Dornbusch, Rudiger, 1976a, "Exchange Rate Expectations and Monetary Policy," Journal of International Economics, Vol. 6 (August), pp. 231-44.

- 1976b, "Expectations and Exchange Rate Dynamics," Journal of Political Economy, Vol. 84 (December), pp. 1161-76.

— 1980, Open Economy Macroeconomics (New York: Basic Books).

, and Paul Krugman, 1976, "Flexible Exchange Rates in the Short Run," Brookings Papers on Economic Activity: 3, Brookings Institution, pp. 537-84.

Flanders, M. June, 1989, International Monetary Economics, 1870-1960: Between the Classical and the New Classical (Cambridge, England: Cambridge University Press).

Fleming, J. Marcus, 1961, "Internal Financial Policies Under Fixed and Floating Exchange Rates,” DM/61/28 (November 8) (Departmental Memorandum), IMF Central Files (S 430, "Exchange Rates 1950").

_ 1962, "Domestic Financial Policies Under Fixed and Under Floating Exchange Rates," Staff Papers, International Monetary Fund, Vol. 9 (November), pp. 369-79.

— 1978, Essays on Economic Policy (New York: Columbia University Press).

, and Robert A. Mundell, 1964, "Official Intervention on the Forward Exchange Market: A Simplified Analysis," Staff Papers, International Monetary Fund, Vol. 11 (March), pp. 1-19.

Frenkel, Jacob A., and Assaf Razin, 1987, "The Mundell-Fleming Model a Quarter Century Later: A Unified Exposition," Staff Papers, International Monetary Fund, Vol. 34 (December), pp. 567-620. 
Galbis, Vicente, 1975, “Monetary and Exchange Rate Policies in a Small Open Economy,” Staff Papers, International Monetary Fund, Vol. 22 (July), pp. 313-43.

Jones, Ronald W., and Peter B. Kenen, 1985, Handbook of International Economics, Vol. 2 (Amsterdam: North-Holland).

Kahn, Richard F., 1931, "The Relation of Home Investment to Employment," Economic Journal, Vol. 41 (June), pp. 173-98.

Kenen, Peter B., 1965, "Trade, Speculation, and the Forward Exchange Rate," in Robert E. Baldwin and others, Trade, Growth and the Balance of Payments: Essays in Honor of Gottfried Haberler (Chicago: Rand McNally \& Co.), pp. 143-69.

— 1985, "Macroeconomic Theory and Policy: How the Closed Economy Was Opened," in Jones and Kenen (1985), pp. 625-77.

— 1994, The International Economy, 3rd ed. (Cambridge, England: Cambridge University Press).

Keynes, John Maynard, 1936, The General Theory of Employment, Interest and Money (London: Macmillan \& Co.).

Krueger, Anne O., 1965, "The Impact of Alternative Government Policies under Varying Exchange Systems,” Quarterly Journal of Economics, Vol. 79 (May), pp. 195-208.

Kumar, Rishi, 1973, "Demand Policies and Internal-External Balance under Fixed Exchange Rates," Weltwirtschaftliches Archiv, Vol. 109, pp. 253-73.

Laursen, Svend, and Lloyd A. Metzler, 1950, "Flexible Exchange Rates and the Theory of Employment," Review of Economics and Statistics, Vol. 32 (November), pp. 281-99.

Levin, Jay H., 1972, "International Capital Mobility and the Assignment Problem," Oxford Economic Papers, Vol. 24 (March), pp. 54-67.

Meade, James E., 1951a, The Balance of Payments: The Theory of International Economic Policy, Vol. 1 (London: Oxford University Press).

- 1951b, The Balance of Payments; Mathematical Supplement: The Theory of International Economic Policy, Vol. 1 (London: Oxford University Press).

Metzler, Lloyd A., 1951, "Wealth, Saving, and the Rate of Interest," Journal of Political Economy, Vol. 59 (April), pp. 93-116.

__ 1960, "The Process of International Adjustment under Conditions of Full Employment: A Keynesian View," paper delivered before the Econometric Society in December 1960, in Readings in International Economics, ed. by Richard E. Caves and Harry G. Johnson (Homewood, Illinois: Richard D. Irwin, Inc., 1968).

Mundell, Robert A., 1960, “The Monetary Dynamics of International Adjustment under Fixed and Flexible Exchange Rates," Quarterly Journal of Economics, Vol. 74 (May), pp. 227-57.

—_, 1961a, “The International Disequilibrium System,” Kyklos, Vol. 14, No. 2, pp. 154-72. , 1961b, "Flexible Exchange Rates and Employment Policy," Canadian Journal of Economics and Political Science, Vol. 27 (November), pp. 509-17.

— 1963, "Capital Mobility and Stabilization Policy under Fixed and Flexible Exchange Rates," Canadian Journal of Economics and Political Science, Vol. 29 (November), pp. 475-85.

— , 2001, "Notes on the History of the Mundell-Fleming Model: Keynote Speech," Staff Papers, International Monetary Fund, Vol. 47 (Special Issue), pp. 215-27.

— 2002, "Notes on the Development of the International Macroeconomic Model," in The Open Economy Macromodel: Past, Present, and Future, ed. by Arie Arnon and Warren Young (Boston: Kluwer Academic Publishers), pp. 1-16. 
Obstfeld, Maurice, and Kenneth Rogoff, 1996, Foundations of International Macroeconomics (Cambridge, Massachusetts: MIT Press).

Polak, Jacques J., 1957, "Monetary Analysis of Income Formation and Payments Problems," Staff Papers, International Monetary Fund, Vol. 6 (November), pp. 1-50.

- 1998, "The IMF Monetary Model at 40," Economic Modelling, Vol. 15 (July), pp. 395-10.

Rodriguez, Carlos, 1979, "Short- and Long-Run Effects of Monetary and Fiscal Policies Under Flexible Exchange Rates and Perfect Capital Mobility," American Economic Review, Vol. 69 (March), pp. 176-82.

Rose, Andrew K., 2000, "A Review of Some of the Economic Contributions of Robert A. Mundell, Winner of the 1999 Nobel Memorial Prize in Economics," Scandinavian Journal of Economics, Vol. 102, No. 2, pp. 211-22.

Steinherr, Alfred, 1975, "Economic Policy in an Open Economy under Alternative Exchange Rate Systems: Effectiveness and Stability in the Short and Long Run," Weltwirtschaftliches Archiv, Vol. 111, pp. 24-51.

Swoboda, Alexander K., 1972, "Equilibrium, Quasi-equilibrium, and Macroeconomic Policy under Fixed Exchange Rates," Quarterly Journal of Economics, Vol. 86 (February), pp. 162-71.

Tobin, James, and Jorge Braga de Macedo, 1980, "The Short-run Macroeconomics of Floating Exchange Rates: An Exposition," in Flexible Exchange Rates and the Balance of Payments: Essays in Honor of Egon Sohmen, ed. by John S. Chipman and Charles P. Kindleberger (Amsterdam: North-Holland), pp. 5-28.

Tower, Edward, 1972, "Monetary and Fiscal Policy in a World of Capital Mobility: A Respecification," Review of Economic Studies, Vol. 39 (July), pp. 251-62.

Tsiang, Sho-Chieh, 1975, "The Dynamics of International Capital Flows and Internal and External Balance," Quarterly Journal of Economics, Vol. 89 (May), pp. 195-214.

Turnovsky, Stephen, and Geoffrey H. Kingston, 1977, "Monetary and Fiscal Policies under Flexible Exchange Rates and Perfect Myopic Foresight in an Inflationary World," Scandinavian Journal of Economics, Vol. 79, No. 4, pp. 424-41. 